\title{
Teacher Assistant in the Inclusive School Environment
}

\author{
Jan Viktorin \\ Department of Special and Inclusive Education, Faculty of Education, Masaryk University, Brno, Czech Republic
}

How to cite this paper: Viktorin, J. (2018). Teacher Assistant in the Inclusive School Environment. The Educational Review, USA, 2(6), 320-329.

http://dx.doi.org/10.26855/er.2018.06.001

Corresponding author: Jan Viktorin, PhDr., Department of Special and Inclusive Education, Faculty of Education, Masaryk University, Brno, Czech Republic.

\begin{abstract}
The literature review deals with the issue of a teacher assistant for pupils with special educational needs in the inclusive school environment, especially the preferred level of education of teacher assistants, qualification assumptions, risks associated with improper involvement of assistants in teaching and the quality and intensity of cooperation between a teacher and a teacher assistant. An analysis of selected studies was used according to two basic thematic criteria: a teacher assistant for pupils with special educational needs and the inclusive school environment. The results of the study have shown that the intensive cooperation of a teacher assistant with a teacher, systematic preparation for lessons and a collective evaluation of assistants' previous work are the most important preconditions for the effective performance. Other factors for the successful teacher assistant's work are an appropriate level of education, knowledge, helpful approach to pupils, empathy and tolerance.
\end{abstract}

\section{Keywords}

Literature Review, Teacher Assistant, Pupil with Special Educational Needs, Support, Inclusive Education

\section{Introduction}

Inclusive education has been promoted in the last two decades as one of the priorities of the Czech educational policy. The concept of inclusion is characteristic of supporting the development of the society in which all individuals participate without any difference. In the field of education, the primary goal of inclusion is to initiate processes leading to increase the quality of the teaching process and to maximize the participation of all pupils in practice, especially maximizing the inclusion of pupils with special educational needs into the educational process of mainstream schools. In recent years, the Czech Republic has been working hard to introduce elements of inclusive education into practical school life (Booth \& Ainscow, 2007; Hájková \& Strnadová, 2010).

The purposeful and meaningful implementation of inclusion in the education process is dependent on many variables and requires comprehensive cooperation between teachers, other school employees, counselling facilities and school counselling centers, pupils, legal representatives of pupils, family, headmasters and representatives of headmasters, representatives of nongovernmental non-profit organizations and state authorities, but also authors of legislative and organizational standards. Teacher assistants are main figures of the wide variety of direct actors in education who can influence the success or failure of inclusive education. The fact remains that the participation of assistants in the educational process of pupils with special educational needs is one of the key elements of inclusive education (Němec, Šimáčková-Laurenčíková \& Hájková, 2014; Teplá, 2015). 
In the educational policy of the Czech Republic, there has been a position of a teacher assistant for more than twenty years. During these years, the job description and use of the name, which refers to these pedagogical workers of supportive character, have been changed. The integral concept of a teacher assistant, whether (s)he works with pupils with health disabilities or with pupils with social disadvantages, was introduced by the Education Act of 2004 and it is still valid with some partial amendments (Uzlová, 2010).

Teacher assistants are pedagogical workers whose activities aim at providing support to another pedagogical worker in the educational process of a pupil or pupils with special educational needs within the scope of the support measure. They help to organize and implement education, promote the autonomy and active involvement of the pupils in all activities carried out at school within the educational framework, including providing school services. Their function and job description are legislatively embedded in standards defining the necessary preconditions for pedagogical workers (the Act on Pedagogical Workers No. 563/2004 Coll., as amended), the basic criteria of education policy (School Act No. 561/2004 Coll., as amended) and forms of support for the educational process of pupils with special educational needs (Decree on the Education of Pupils with Special Educational Needs and of Gifted Pupils No. 27/2016 Coll., as amended) (MEYS CR, 2016; Morávková Vejrochová et al., 2015; Němec et al., 2014).

To some extent, the description of the teacher assistant job is determined by competences of schools, especially school leaders. A certain binding, very generally conceived basis provides a Decree on the Education of Pupils with Special Educational Needs and of Gifted Pupils (No. 27/2016 Coll.), which sets out main activities of a teacher assistant (§ 5): "assistance in educational activities and assistance in communicating with pupils, legal representatives of pupils and the community from which the pupil comes; helping pupils to adapt to the school environment; helping pupils to learn and to prepare for lessons; the necessary assistance to pupils for self-help and the movement during lessons and events organized by the school outside the place where the school, in accordance with the registration in the school register, is providing education or school services; other activities mentioned in Government Order No. 222/2010 Coll., On the Catalog of Works in Public Services and Administration" (MEYS CR, 2016).

\section{Methodology}

The literature review explores the question of teacher assistants' work with pupils with special educational needs under conditions of inclusive education. We have defined two basic thematic criteria for the selection of studies which are suitable for this analysis: a teacher assistant for pupils with special educational needs and the inclusive school environment. We have tried to approach the chosen topic for the literature review in a comprehensive way. In the process of the literature review, we asked the following research questions: What is the preferred level of education of a teacher assistant? What are other qualification preconditions, abilities, skills and character traits important to assistants? What are the risks associated with improper involvement of assistants in the process of teaching? What is the quality and intensity of cooperation between a teacher assistant and a teacher?

For this purpose, we have selected and analyzed nineteen monographs, chapters in monographs, specialized papers and documents that deal with the chosen topic. The collection and study of the professional literature of domestic and foreign origin carried out in the middle of 2016. We searched the titles for the literature review in Web of Science, ERIH, Scopus and online catalogs of the National Library in Prague and the Moravian Library in Brno. The selection was limited to full-text sources available in the online version or in library funds. We focused on thematic publications in the time period between 2005 and 2014. Based on the established criteria for the text selection and according to the analysis, we synthesized findings from the relevant studies into the literature review. In the systematic review, we tried to analyze the selected papers, to give their brief characteristics, to distinguish and pick out their specifics, to evaluate their contribution to theory and practice and to 
include the knowledge about the topic of teacher assistants' work in conditions of inclusive education. The following table provides the general overview of the selected studies.

Table 1. Overview of the analyzed studies on the role of teacher assistant at school.

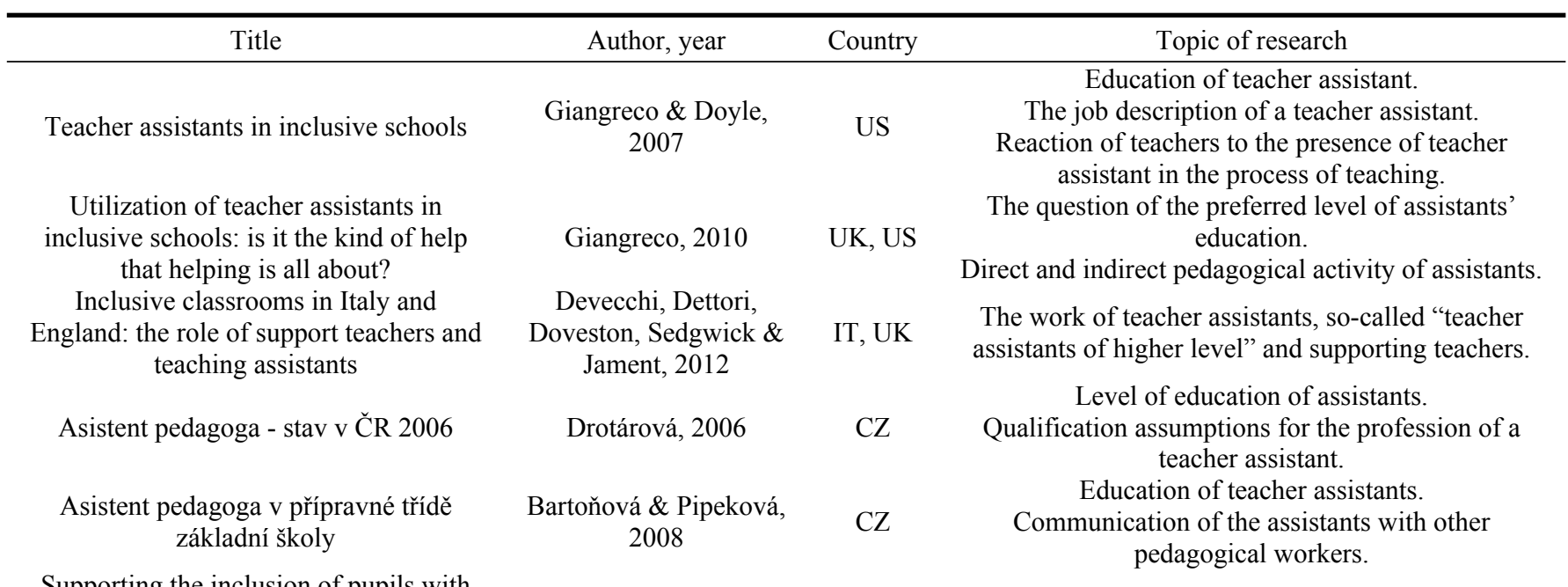

Groom \& Rose, 2005

UK Personality preconditions for teacher assistant work.

difficulties in the primary school: the role of teaching assistants

Asistence lidem s postižením a

znevýhodněním: praktický průvodce pro osobní a pedagogické asistenty

Asistent pedagoga v inkluzivní škole

Assistance to pupils with physical disabilities in regular schools: promoting inclusion or creating dependency?

School factors that facilitate or hinder the ability of teaching assistants to effectively support pupils with autism spectrum disorders (ASDs) in mainstream secondary schools

Including pupils with autistic spectrum disorders in the classroom: The role of teaching assistants

Double standards and first principles: framing teaching assistant support for pupils with special educational needs

Looking for some different answers about teaching assistants

Uzlová, 2010

CZ Preferred personality qualities of teacher assistants.

Němec, Šimáčková Laurenčíková \& Hájková, 2014

$\mathrm{CZ}$

Egilson \& Traustadottir, 2009

IS

Symes \& Humphrey, 2011

UK

Preferred traits, abilities and skills of a teacher assistant.

The work of assistant with pupils.

Formulation of the job description of teacher assistants.

Negative impacts of pupils' assistant support.

Risk of social isolation of pupils in terms of assisting support.

Factors influencing the ability of teacher assistants to include pupils effectively.

Symes \& Humphrey, 2012

UK

Involvement in educational processes of pupils.

Barriers in the social inclusion of pupils resulting from the teacher assistant's presence.

Direct and indirect pedagogical activities of assistants.

Webster, Blatchford, Bassett, Brown, Martin \& Russell, 2010

Weaknesses in the interaction between assistants and supported pupils.

Weaknesses in the area of cooperation between assistants and teachers.

Balshaw, 2010

UK

Risks in assistant work with pupils.

Key players in inclusion: are we meeting the professional needs of learning support assistants for pupils with complex needs?

Do classroom assistants work?

Výsledky prieskumu o postavení žiaka zo sociálne znevýhodněného prostredia $\mathrm{V}$

Abbott, McConkey \&

Dobbins, 2011

Woolfson \& Truswell, 2005

Š́ndorová, 2011
UK

UK

SK
Differences in teacher assistant work.

Engaging pupils' parents into education through assistant services.

Effectiveness of the teacher assistant support. 


\begin{tabular}{|c|c|c|c|}
\hline Title & Author, year & Country & Topic of research \\
\hline \multicolumn{4}{|l|}{ základnej škole - 2. čast' } \\
\hline $\begin{array}{c}\text { The shifting role of the special needs } \\
\text { assistant in Irish classrooms: a time for } \\
\text { change? }\end{array}$ & $\begin{array}{l}\text { Keating \& O’Connor, } \\
2012\end{array}$ & IE & $\begin{array}{l}\text { Factors influencing the quality of cooperation } \\
\text { between a teacher assistant and a teacher. }\end{array}$ \\
\hline $\begin{array}{l}\text { Edukace sociálně znevýhodněných žáků z } \\
\text { pohledu asistentů pedagoga brněnských } \\
\text { základních škol }\end{array}$ & $\begin{array}{l}\text { Němec \& Štěpařová, } \\
2008\end{array}$ & $\mathrm{CZ}$ & $\begin{array}{l}\text { The job description of the teacher assistants. } \\
\text { Level of cooperation between assistants and } \\
\text { educators. }\end{array}$ \\
\hline
\end{tabular}

\section{Results of the Review}

\subsection{Education of Teacher Assistant}

The area of preferred education of teacher assistants reflects many foreign and several domestic research studies. In their comparative study, Giangreco and Doyle (2007) produced 20 research studies and related specialized papers from England, Italy, Australia, Sweden and the USA. The comparative work has repeatedly agreed with the fact that the level of qualification of teacher assistants is rather inconsistent and that most of assistants are not university graduates. Teacher assistants get the position without prior experiences in the area of education or special education, and they usually do not receive any training and supervision during their employment. The authors also draw attention to discrepancies in the teacher assistants' role development and the constitution of their roles in line with the needs of educators and pupils, school conditions and possibly other influences.

According to Giangreco's study (2010), which compares the involvement of teacher assistants in the United States and England, education of assistants is often at an inappropriate level, and assistants also undertake tasks for which they do not have an appropriate education. A higher level of education does not always have an advantage in the assistant work. The research also mentions the lack of time for assistants and educators to jointly plan teaching activities and unwanted but relatively common practice when assistants are in the position of main educators of pupils with special educational needs. Devecchi, Dettori, Doveston, Sedgwick and Jament (2012), based on outputs from three research studies, compared the work of teacher assistants (and so-called "teacher assistants of higher level") in Great Britain and supporting teachers in Italy. In the case of British teacher assistants, problems often arise from their lower professional qualifications and hence from a lower, subordinate position within the pedagogical staff. In the case of supporting teachers in Italy who are university-educated teachers with the superstructure course, problems arise when other teachers are relieved of their responsibility for the educational process of pupils with special educational needs through the presence of supporting teachers.

The issue of teacher assistants' education has been discussed in several Czech research studies focused on the work of assistants in classrooms with pupils with social disadvantages. Drotárová's research (2006) refers to the predominance of teacher assistants without a school-leaving certificate who work with pupils with social disadvantages. In the school year $2005 / 2006$, more than $50 \%$ of 240 working teacher assistants had basic education or secondary education without a school-leaving certificate, less than one-third of the assistants had secondary education with a school-leaving certificate, and only $2.5 \%$ were graduates. It is worth mentioning the research study of Bartoňová and Pipeková (2008), which carried out in the school year 2006/2007 in preparatory classrooms for pupils with social disadvantages, $25 \%$ of 97 assistants had only a basic education, more than $50 \%$ secondary education and about one-tenth of them had a higher education.

\subsection{Preferred Traits, Skills and Abilities of Teacher Assistant}


In addition to the obtained level of education, other qualification preconditions, skills and abilities are essential for the position of a teacher assistant. These preconditions were mentioned by Groom and Rose (2005), 94 schools with assistants working with pupils with social, emotional and behavioral difficulties participated in this research. The schools in the process of selection of candidates for the position of a teacher assistant emphasize several personal qualities: ability to work as a team member, willingness to learn, adaptability, tolerance and sense of justice, ability to bring up, ability to listen, ability to work under pressure / work alone, understanding and awareness of the needs of pupils. According to Groom and Rose' research results, the teacher assistant is necessary for the effective inclusion of pupils with social, emotional and behavioral problems into "regular" classrooms.

To explore the qualification preconditions for the profession of a teacher assistant in the Czech environment was used a questionnaire survey by Drotárová (2006). There was included positive relationship to children, then empathy, communicativeness and patience among the most important of the preferred traits and abilities of a teacher assistant working with pupils with social disadvantages. The individual participants of the educational process agree on some qualification preconditions, however, the preferences of assistants, teachers and headmasters differ in some of personal dispositions. Empathy, patience and willingness to help are considered by teacher assistants to be more important than by their superiors. Assistants, teachers and headmasters put three qualities on equal terms - honesty, friendliness and knowledge of the specific environment. Further, assistants consider consistency, willingness to cooperate, diligence, independence and responsibility as less important. From the position of headmasters, more stress is placed on responsibility, on willingness to learn and on knowledge assumptions. From the position of teachers, consistency and creativity are emphasized. In her study, the author also compared the official job descriptions of teacher assistants focusing on socially disadvantaged pupils with assistants' statements. The four forms of activity (activities related to social pathological phenomena, pupil tutoring, pupil supervision and conflict situation resolution) were in practice more often required by assistants than would correspond to their official job description.

Based on the experience with pupils with health disabilities, Uzlová (2010) specified the preferred personal qualities of teacher assistants. According to her final results, the work performance of assistant assumes complex personal dispositions. A teacher assistant should have a motivated and balanced personality with a positive and open attitude. The main basic characteristics are communicativeness, creativity, flexibility, ability to work in a team, reliability, patience, friendliness, empathy, kindness, consistency and responsibility. Furthermore, (s)he should be able to set boundaries in relation to an educator, a pupil, his classmates, parents, and to find an appropriate balance in these relationships.

Němec, Šimáčková-Laurenčíková and Hájková (2014) conducted a research study during the school year 2012/2013 in 25 mainstream primary schools. The authors tried to create the most comprehensive view of the preferred qualities, abilities and skills of teacher assistants, so they questioned not only assistants but also cooperating teachers, headmasters or representatives of headmasters and, last but not least, pupils with special educational needs with whom the assistants work. In the final evaluation of all participants' responses, the most important criterion for the profession of teacher assistants seems to be a friendly approach to pupils. Other required skills and abilities of assistants are education, knowledge, empathy, understanding of pupils' needs and patience with the progress of individual pupils.

\subsection{Work of Assistant with Pupils}

The issue of teacher assistants' work with pupils can be explored from various views, here is worth mentioning risks associated with inappropriate involvement of assistants in the educational process as well as potential assistants' shortcomings. It is important to point out increased risk of stigmatization and social isolation in pupils with special educational needs to whom is given the teacher assistant's support. This negative impact of the assistance for pupils with physical disabilities is mentioned 
by Egilson and Traustadottir (2009). These Icelandic researchers recognized that assistants make a significant contribution to encouraging participation and learning process of pupils with health disabilities, however, at the same time they pointed out the fact that the permanent assistant's presence can cause the limited use of pupils' strengths and create an unhealthy dependence.

Symes and Humphrey (2011) refer to the increased risk of social isolation of pupils from the view of assisting support in the educational process of pupils with autism spectrum disorder (ASD), but also relativize the negative aspect of this social isolation. The research also states factors perceiving as a facilitating or defending ability of teacher assistants to integrate pupils with ASD effectively. These factors include the access to professional knowledge, communication inside the school and pedagogical employees' awareness of ASD.

In another study, Symes and Humphrey (2012) compared involvement of pupils with ASD and pupils with dyslexia and pupils without disabilities in the teaching process. The analysis shows that the involvement of pupils with ASD in the teaching process as well as the involvement in the social climate of their classroom was less effective compared to the other two groups of pupils. The presence of a teacher assistant even deepened the differences between the groups. For pupils with ASD, the authors specified two difficulties in social inclusion caused by the teacher assistant's participation during the lessons. If the assistant sat next to a pupil with ASD, other pupils communicated more with the assistant than with the pupil with ASD. The pupil with ASD was used to cooperate more with the assistant than with other classmates. If the assistant was missing, pupils with ASD preferred to work on their own.

In this context, Webster, Blatchford, Bassett, Brown, Martin and Russell (2010) deal with a significant aspect of the teacher assistant's work with pupils in the interpretation of the Deployment and Impact of Support Staff project carried out in British schools. As one of the most interesting results of the research may be determined findings related to the impact of teacher assistants' work on the academic progress of pupils (in language, mathematics and natural sciences). The research has shown that pupils with special educational needs supported by a teacher assistant have had worse outcomes than pupils with limited assistance services or pupils without the assistance services. Based on the poor results of pupils with the assistant support, the authors point out that teacher assistants have a lower education compared with the education of teachers and qualified teachers prefer working with pupils who do not have special educational needs.

This negative aspect is reflected in Balshaw's research study (2010), which presents that the pupils who need purposeful, expert and highly educated attention the most do not receive the attention at all.

Webster et alii (2010) also discuss other more frequent deficiencies in the interaction between assistants and supported pupils. In comparison with teachers, assistants more often help the pupils, answer instead of pupils, provide pupils confusing or incorrect interpretation of the school curriculum. Assistants focus more on the task achievement without verifying whether pupils have understood the lesson and whether they have acquired the specific knowledge.

Differences in the teacher assistants' work have been demonstrated in the research dealing with the support of pupils with multiple disabilities or severe disabilities. Abbott, McConkey and Dobbins (2011) focused the research study on the teacher assistants working with pupils with multiple disabilities in Northern Ireland. The final results provided information that the activity of these assistants was based on the pedagogical support and health support. Three-quarters of the assistants declared that the most important part of their work was to help pupils with health and medical treatment, about $30 \%$ of them said they were giving medication to their pupils, even through the intravenous medication use.

Involving parents in their children's education can be an important part of teacher assistant's work, especially with pupils with social disadvantages. Woolfson and Truswell (2005) dealt with the work of assistants in a project aimed at supporting the education of pupils with social disadvantages in schools in Scotland. The authors used parents' statements in the research which led to the results that only $30 \%$ of the parents got involved more in the educational process of their child due to the service of a teacher assistant. On the other hand, almost three-quarters of the addressed parents agreed with the positive 
impacts of the work of an assistant on a child, especially in reading and orthography.

For education practice, there is an essential question how to divide the teacher assistants' support into more classes. Šándorová (2011) carried out her research in seven hundred primary schools educating pupils with social disadvantages in the Slovak Republic. The effectiveness of the teacher assistant's work is demonstrably higher if (s)he stays more hours in one class, there is as well a small difference in the number of missed lessons between pupils from a socially disadvantaged environment and pupils in total.

Němec et alii (2014) focused on the forms of support provided by assistants to pupils with special educational needs. The findings that the teacher assistant works in the classroom during lessons under teacher supervision is considered as a significant fact. Then, the authors focused on the essential areas of assistant support from the view of pupils with special educational needs. In this context, as one of the main work responsibilities is regarded the support if teacher assistant in the lessons of elementary subjects (Czech language, Mathematics). Pupils with social disadvantages also needed the assistance in English lessons, while pupils with health disabilities required help in Arts. The research study detected a positive attitude towards pupils with health disabilities, where both headmasters and teachers perceived a teacher assistant as an equal pedagogical worker in a class and used his/her support in a range of activities.

\subsection{Cooperation between Assistant and Teacher}

According to the selected studies, the quality and intensity of cooperation between an assistant and a teacher are very different. The differences depend on previous preparation for common cooperation, the time spent on joint preparation for lessons as well as on communication competencies between assistants and teachers. The authors Giangreco and Doyle (2007) point to various teacher reactions to the presence of the teacher assistant in class. Some teachers welcome the assistant and appreciate the presence in the class, however, on the other hand, some teachers have a problem with the acceptance of another pedagogical worker in the class.

Webster et alii (2010) mentioned numerous gaps connected with the teacher assistant's presence in a class. According to this research study in the UK, $65 \%$ of the participated educators working in the classroom with an assistant had never passed any organized preparation for cooperation with the teacher assistant. The remaining 35\% of the teachers had attended a short-term course focused on cooperation with the assistant, yet only the half of the respondents evaluated the course as an effective preparation.

Furthermore, the authors declared that three-quarters of teachers did not have any time for joint preparation with their assistants and providing feedback for assistants. It did not mean that the assistants and the teachers did not prepare for the teaching process and did not communicate together at all, but the preparation and communication often took place outside normal working hours, which is unpaid time. The mentioned study also reflects the division of the work responsibilities of assistants into a direct pedagogical activity and an indirect pedagogical activity. The direct pedagogical activity includes the work with pupils, for instance, the support in the processing of educational tasks, individual and group teaching. The indirect pedagogical activity is administration work in particular. Based on the division of pedagogical activities in the UK, a large part of the workday of assistants is devoted to the direct work - different pedagogical and supportive tasks in direct interaction with pupils, supplemented with activities to help the educator and support the educational programs.

Factors affecting the quality of cooperation between an assistant and an educator are not only time for joint preparation, but also the participation of teacher assistants at meetings of pedagogical staff. Keating and O'Connor (2012) found that almost $50 \%$ of the assistants and cooperating teachers in Ireland did not have any dedicated time for simultaneous lesson planning in their timetable and that more than $60 \%$ of assistants are not invited to teacher meetings or similar teachers' meeting.

In Czech research studies, we can also see varied levels of cooperation between assistants and teachers. Němec and Štěpařová 
(2008) discussed that the assistants' presence at their staff meetings often emphasized good experience with cooperation with educators. Assistants also mentioned the fact that if a teacher assistant fulfils his/her position in a class, he can become a social model for pupils. It is desirable for assistants to devote more attention to pupils in their free time and to support them even if they are at risk of various social pathological phenomena. Consequently, the authors compared many job descriptions related to teacher assistant positions. In all official job descriptions written by school headmasters, professional expectations of the school management were broad ranging from pedagogical-psychological works to a technical nature.

Bartoňová and Pipeková (2008) were interested in the cooperation between educators and assistants in the Czech Republic as well. Regarding the research results, the communication with other pedagogical workers is the most problematic area in the practice of assistants. Nearly $40 \%$ of the assistants also claimed that educators did not respect them in classes.

The newest Kratochvílová's research study (2013) demonstrates that due to the increasing number of pupils in need of assistance, educators are more aware of the necessary position of a teacher assistant in each class. They admit that they are gradually learning the reciprocal cooperation, but they have defined roles in the class today. Educators nowadays appreciate their assistants because they give them feedback on their teaching and require the teachers to stimulate active participation of all pupils in the process of learning, not just pupils with special educational needs. The study provides an interesting insight into headmasters' experience. They present their opinions on the length of interaction between assistants and teachers. If a teacher and an assistant are a well-balanced team, it is advisable to support their cooperation for more than a year to improve and deepen it.

\section{Conclusion}

The appropriate level of completed education is one of the most important preconditions for the effective performance of teacher assistants' work. In the case of assistance in a group of pupils with health disabilities, the emphasis is on the higher education of teachers. The level of education of assistants working in classes with pupils with social disadvantages is not a preferred condition (Bartoňová \& Pipeková, 2008; Devecchi et al., 2012; Drotárová, 2006; Giangreco \& Doyle, 2007; Giangreco, 2010).

The authors define an adequate level of education and knowledge, empathy, tolerance and positive and open attitude towards pupils as the most important preconditions for the work of a teacher assistant. It is necessary to mention that attention is also focused on the preferred characteristics of assistants according to the nature of pupils' special educational needs. If assistants work with pupils with health disabilities, these assistants are expected to have an appropriate education for this work. Nevertheless, in the case of assistants working with pupils with social disadvantages, there is preferred a good relationship between assistants and pupils and the assistant's level of education is secondary. The preferred abilities, character traits and skills of a teacher assistant depends on the needs of pupils and teachers. Last but not least, it is supposed that there is a balance between the level of completed education and the character traits of assistants (Drotárová, 2006; Groom \& Rose, 2005; Němec, Šimáčková-Laurenčíková \& Hájková, 2014; Uzlová, 2010).

Teacher assistants may contribute to the development of independence of pupils with special educational needs, the assistants' work does not ease the process of learning and assistants do not perform activities instead of pupils, they encourage pupils to work independently. However, the research studies have registered that teacher assistants' support cause social isolation of pupils with special educational needs. Assistants working with pupils with social disadvantages follow the concept of teacher assistants' activities, they deal with a number of different pupils and provide indirect support in the process of education. On the contrary, assistants working with pupils with health disabilities aim all their activities at a direct support of pupils with health disabilities. These assistants often overtake the role of primary educators of pupils with health disabilities (Abbott et al., 2011; Balshaw, 2010; Egilson \& Traustadottir, 2009; Němec et al., 2014; Symes \& Humphrey, 2011, 2012; Šándorová, 2011; 
Webster et al., 2005).

The level of cooperation between teacher assistants and teachers has had a positive value, but at the same time, teachers have complained about the time pressure and workload of assistants and as well about their inappropriate education. Teachers and assistants have mentioned difficulties at the beginning of cooperation associated with a lack of teachers' experience in the environment of secondary schools and insufficient communication between teachers and assistants (Bartoňová \& Pipeková, 2008; Giangreco \& Doyle, 2007; Keating \& O’Connor, 2012; Kratochvílová, 2013; Němec \& Štěpařová, 2008; Webster et al., 2010).

From these conclusions, it is evident that the effective and optimal involvement of a teacher's assistant in education in mainstream schools is often a very difficult process. The first criterion for selecting a teacher assistant is based on valid legislation. However, this criterion is not sufficient for the effective work of a teacher's assistant. Therefore, it is necessary to select a suitable worker as a teacher assistant according to a personal consultation and appropriate professional profile, to clearly formulate the content of his/her work, to identify the forms of support for pupils with special educational needs and to ensure an optimal level of cooperation between the teacher assistant and the teacher.

\section{References}

Abbott, L., McConkey, R., \& Dobbins, M. (2011). Key Players in Inclusion: Are We Meeting the Professional Needs of Learning Support Assistants for Pupils with Complex Needs? European Journal of Special Needs Education, 26(2), 215-231.

Balshaw, M. (2010). Looking for Some Different Answers about Teaching Assistants. European Journal of Special Needs Education, 25(4), 337-338

Bartoňová, M., \& Pipeková, J. (2008). Asistent pedagoga v př́ípravné třídě základní školy. In M. Bartoňová \& M. Vítková et al., Vzdělávání žáků se speciálními vzdělávacími potrebami II (s. 229-244). Brno: Paido.

Booth, T., \& Ainscow, M. (2007). Ukazatel inkluze: rozvoj učení a zapojení ve školách. Praha: Rytmus.

Devecchi, C., Dettori, F., Doveston, M., Sedgwick, P., \& Jament, J. (2012). Inclusive Classrooms in Italy and England: The Role of Support Teachers and Teaching Assistants. European Journal of Special Needs Education, 27(2), 171-184.

Drotárová, L. (2006). Asistent pedagoga - stav v ¿̌R 2006. Praha: IPPP, 2006.

Egilson, S. T., \& Traustadottir, R. (2009). Assistance to Pupils with Physical Disabilities in Regular Schools: Promoting Inclusion or Creating Dependency? European Journal of Special Needs Education, 24(1), 21-36.

Giangreco, M. F. (2010). Utilization of Teacher Assistants in Inclusive Schools: Is It the Kind of Help that Helping Is All About? European Journal of Special Needs Education, 25(4), 341-345.

Giangreco, M. F., \& Doyle, M. B. (2007). Teacher Assistants in Inclusive Schools. In L. Florian (Ed.), The SAGE Handbook of Special Education (p. 429-439). London: Sage.

Groom, B., \& Rose, R. (2005). Supporting the Inclusion of Pupils with Social, Emotional and Behavioural Difficulties in the Primary School: The Role of Teaching Assistants. Journal of Research in Special Educational Needs, 5(1), 20-30.

Hájková, V., \& Strnadová, I. (2010). Inkluzivni vzděláváni: teorie a praxe. Praha: Grada.

Keating, S., \& O'Connor, U. (2012). The Shifting Role of the Special Needs Assistant in Irish Classrooms: A Time for Change? European Journal of Special Needs Education, 27(4), 533-544.

Kratochvílová, J. (2013). Inkluzivni vzděláváni v české primárni škole: teorie, praxe, výzkum. Brno: Masarykova univerzita.

MEYS CR. (2016). Decree No. 27/2016 Coll., on the Education of Pupils with Special Educational Needs and of Gifted Pupils. Retrieved from http://www.zakonyprolidi.cz/cs/2016-27

Morávková Vejrochová, M., Gardošová, J., Korandová, V., Koutská, M., Kulštrunková, J., Kusá, O., Luhanová, A., Michalík, J., Němec, Z., Obrovská, L., Soudná, K., \& Tlapáková, I. (2015). Standard práce asistenta pedagoga. Olomouc: Univerzita Palackého.

Němec, J., \& Štěpařová, E. (2008). Edukace sociálně znevýhodněných žáků z pohledu asistentů pedagoga brněnských základních škol. In M. Bartoňová \& M. Vítková et al., Vzděláváni žáků se speciálními vzdělávacími potřebami II (s. 245-262). Brno: Paido.

Němec, Z., Šimáčková-Laurenčíková, K., Georgieva, R., Horáčková, K., Titěrová, K., Šebová, B., \& Čurejová, J. (2014). Asistence ve vzděláváni žáků se sociálním znevýhodněním. Praha: Nová škola.

Němec, Z., Šimáčková-Laurenčíková, K., \& Hájková, V. (2014). Asistent pedagoga v inkluzivní škole. Praha: Univerzita Karlova.

Symes, W., \& Humphrey, N. (2011). School Factors that Facilitate or Hinder the Ability of Teaching Assistants to Effectively Support Pupils 
with Autism Spectrum Disorders (ASDs) in Mainstream Secondary Schools. Journal of Research in Special Educational Needs, 11(3), 153161.

Symes, W., \& Humphrey, N. (2012). Including Pupils with Autistic Spectrum Disorders in the Classroom: The Role of Teaching Assistants. European Journal of Special Needs Education, 27(4), 517-532.

Šándorová, V. (2011). Výsledky prieskumu o postavení žiaka zo sociálne znevýhodneného prostredia v základnej škole. 2. čast'. Pedagogické rozhl'ady: odborno-metodický časopis, 20(5), 22-23.

Teplá, M. (2015). Asistent pedagoga: jak efektivně zavést pozici asistenta pedagoga ve školách. Praha: Verlag Dashöfer.

Uzlová, I. (2010). Asistence lidem s postižením a znevýhodněnim: praktický průvodce pro osobni a pedagogické asistenty. Praha: Portál.

Webster, R., Blatchford, P., Bassett, P., Brown, P., Martin, C., \& Russell, A. (2010). Double Standards and First Principles: Framing Teaching Assistant Support for Pupils with Special Educational Needs. European Journal of Special Needs Education, 25(4), 319-336.

Woolfson, R. C., \& Truswell, E. (2005). Do Classroom Assistants Work? Educational Research, 47(1), 63-75. 